\title{
Dietary supplement use and knowledge among students from a health science faculty in a Turkish University
}

\author{
*Erzurum Alim, N., Karakaya, R.E. and Turk Fidan, O.P. \\ Department of Nutrition and Dietetics, Faculty of Health Sciences, Ankara Ylldırım Beyazlt University, \\ Ankara, Turkey
}

\begin{abstract}
Article history:
Received: 22 December 2020

Received in revised form: 29

January 2021

Accepted: 21 April 2021

Available Online: 19

September 2021
\end{abstract}

\section{Keywords:}

Dietary supplements,

Diet,

University students,

Nutrition

\section{DOI:}

https://doi.org/10.26656/fr.2017.5(5).760

\begin{abstract}
Dietary supplements are concentrated sources of nutrients used as an addition to a normal diet with a nutritional or physiological effect. In this cross-sectional study, it was aimed to determine the factors of dietary supplement use, the related knowledge, and their relationship with supplement use in a faculty of health sciences among university students. This cross-sectional study was carried out with 333 voluntary university students from Ankara Y1ldirım Beyazıt University, the Faculty of Health Sciences. A questionnaire form consisting of 5 sections was applied to the students by face-to-face interview method. The most remarked purposes of supplement use were to improve health $(44.2 \%)$ and boost immunity (22.1\%). There was no difference between age, gender, department, coexistent disease, tobacco smoking and alcohol consumption in terms of dietary supplement use (p $=0.611, \mathrm{p}=0.720, \mathrm{p}=0.682, \mathrm{p}=0.062, \mathrm{p}=0.491$, and $\mathrm{p}=0.658$, respectively). No significant difference was observed between physical activity status, the duration of physical activity, dieting status, the source of diet program, daily frequency of main meals and snacks, body mass index (BMI) groups, and the reason for meal skipping among students according to dietary supplement use $(\mathrm{p}=0.180, \mathrm{p}=0.205, \mathrm{p}=0.686, \mathrm{p}=0.226, \mathrm{p}$ $=0.533, p=0.449, p=0.976$, and $p=0.758$, respectively). There was not any significant difference between physical activity status, the duration of physical activity, dietary supplement use, dieting status, the frequency of main meals and snacks and BMI in terms of total knowledge score of dietary supplements $(\mathrm{p}=0.245, \mathrm{p}=0.713, \mathrm{p}=0.278, \mathrm{p}=$ $0.067, p=0.466, p=0.647$, and $p=0.851$, respectively). Scientific attention should be paid to the use of dietary supplements. Arbitrary approaches can lead to unwanted interactions. Therefore, in order for health and government policies to be established related to dietary supplements, it is essential to determine the factors related to their use.
\end{abstract}

\section{Introduction}

Dietary supplements are concentrated sources of nutrients used as an addition to a normal diet with a nutritional or physiological effect (EFSA, 2020; EC, 2020). In other words, it is defined as the available forms of nutrients corresponding to high doses in the form of pills, capsules, or syrups. These products generally have a wide range, including vitamins, minerals, amino acids, essential fatty acids, pulp, various herbs, and their extracts (Tek and Pekcan, 2008). These single or multicomponent products can be quite different in their characteristics (Karaarslan et al., 2019).

These supplements are products that should be used with expert advice in cases where nutrition is not sufficient. However, they may be widely used in an uncontrolled way all over the world (Karaarslan et al., 2019). While the food supplement market in Turkey is growing each day, supplement use habits are also affected directly proportional (Bozkurt Bekoğlu and Ergen, 2016). In Turkey, the prevalence of using dietary supplements in individuals who exercise was $43-47.6 \%$ (Babal, 2015; Helvac1, 2017). Furthermore, $10.7 \%$ of university students used nutritional supplements (Kara, 2019). The prevalence of dietary supplement use in college or university students in other countries was also reported and was found to be in the $16.8-69 \%$ range (Axon et al., 2017; Barnes et al., 2016; Gajda et al., 2017; Naqvi et al., 2019; Radwan et al., 2019; Serdarevic et al., 2019).

The university period is a transition phase in which the late stages of adolescence and the first period of 
adulthood begin. When young people leave the family environment, their stress levels increase and their nutritional status changes accordingly. They are more affected by external factors and begin to make their own free choices prominently (Akdevelioğlu and Yörüsün, 2019). In this period, as well as the adaptation of students to a new discipline, the faster pace of life they lead also increases unhealthy and irregular nutrition behaviours (Kartal et al., 2017). Zemzemoğlu et al. (2019) found high levels of main meal skipping and snack consumption among students from a faculty of health science. Also, these students were not physically active enough in Arslan's study. In addition, habits such as not drinking enough water and milk and preferring fast food were determined to increase in this period (Arslan et al., 2016).

The types of supplements used vary depending on studies (Barnes et al., 2016; Kobayashi et al., 2017). Barnes et al. (2016) found mostly vitamin and mineral use in the Australian university population. While health anxiety in university students has been increasing over the recent years, in many studies students can use dietary supplements to support their immunity and to maintain and improve their health in this environment (Sharma and Adiga, 2014; Ünsal et al., 2010; Radwan et al., 2019; Kosic et al., 2020). These products are used by people who are of the opinion that nutrition will cure their diseases (Erden and Tanyeri, 2004). The prevention of weakness, increasing physical and mental performance, muscle development, and fat burning were among the reasons for supplement use stated in other studies (Babal, 2015; Bekoğlu and Ergen, 2016). However, it should be considered that random approaches about supplements may lead to inadequate treatment of certain diseases, delayed diagnosis by concealing some symptoms, and latent drug interactions (Erden and Tanyeri, 2004).

Understanding the characteristics of dietary supplement consumers, their awareness levels, and usage rates of the products is important in determining the strategy for healthcare professionals, producers, and the government (Bekoğlu and Ergen, 2016). In this crosssectional study, it was aimed to determine the factors of dietary supplement use, the related knowledge, and their relationship with supplement use in a faculty of health sciences among university students.

\section{Materials and methods}

This cross-sectional study was carried out with 333 voluntary university students from Ankara Y1ldırım Beyazit University, the Faculty of Health Sciences from May to September 2019, in Ankara, Turkey. A questionnaire form consisting of 5 sections was applied to the students by face-to-face interview method. Data in the questionnaire forms were kept confidential. The study was approved by the Institutional Review Board and Ethics Committee of Ankara Yıldırım Beyazıt University (Project No: 2019-197) and all the subjects gave written informed consent in accordance with the Declaration of Helsinki.

\subsection{Demographic information of students}

The section consists of demographic characteristics such as department, age, gender, tobacco smoking, alcohol consumption, coexistent diseases, physical activity status and duration, dieting status and the source of diet program, which were used to assess the general information about students.

\subsection{Nutritional habits}

The frequency of daily main meals and snacks and the reason for meal skipping were questioned to determine the nutritional habits.

\subsection{Anthropometric measurements}

Students' body weight and height were measured by a trained researcher. Body weight was measured via Tanita Body Composition Analyzer UM-073. The participants were asked to wear light clothes and be barefoot during the procedure. Seca 206 stadiometer was used to measure height. The students were aligned in a standing position with head at Frankfort plane. After obtaining body weight and height, BMI was calculated. The formula 'weight $(\mathrm{kg}) /$ height $\times$ height $\left(\mathrm{m}^{2}\right)$ ' was used to assess BMI and the obtained results were categorized according to the WHO criteria (WHO, 2020).

\subsection{Habits of dietary supplement use}

The use of the dietary supplement, the supplement type, the place of purchase of the product, the duration of use, and the purpose of use was questioned in this section.

\subsection{Level of knowledge on dietary supplements}

Students' level of knowledge was evaluated via 10 multiple choice questions based on their declaration (true, false, I do not know). The questions included in this section were: 'Additional vitamin-mineral use is absolutely necessary.' 'Vitamins energize the body.', 'Antioxidants have no effect on the immune system.', 'Every herbal product is harmless.' 'Anyone can use multivitamins.', 'It is not necessary to consult a doctor to use dietary supplements.', 'The dosage is not important to us when using dietary supplements.', 'Vitaminsminerals taken more than necessary will not be harmful.', 'Protein supplements above the requirement 
should be used to increase muscle mass.', and 'Dietary supplements do not interact with medicines, foods and beverages.'. Only the correct answers were scored as ' 1 ' and the wrong answers and the answers of 'I don't know' were scored as ' 0 '. The total knowledge score was calculated between ' 0 ' and ' 10 '.

\subsection{Statistics}

Continuous numerical variables were transformed into sequential qualitative (categorical) data and included in the analysis. The relationship (independence) between categorical variables was analyzed by chi-square tests and reported with the exact p-value. The relationship between continuous qualitative variables was analyzed with Goodman-Kruskal's gamma test. The significance level was accepted as $0.05(5 \%)$ and the data obtained were analyzed with SPSS (Statistical Package for Social Sciences, version 25).

\section{Results}

The study included 333 university students, of whom $28.5 \%$ declared that they used dietary supplements. The dietary supplement that was mainly used was multivitamins $(25.3 \%)$ and omega-3 (24.2\%). The students generally preferred to purchase the supplements from the pharmacy $(95.8 \%)$. Of the students, $51.1 \%$ stated one month of duration on supplement use. The most remarked purposes of supplement use were to improve health (44.2\%) and boost immunity (22.1\%) (Table 1).

Table 2 demonstrates that there is no difference between age, gender, department, coexistent disease, tobacco smoking and alcohol consumption in terms of dietary supplement use $(p=0.611, p=0.720, p=0.682$, $\mathrm{p}=0.062, \mathrm{p}=0.491$, and $\mathrm{p}=0.658$, respectively).

No significant difference was observed between physical activity status, the duration of physical activity, dieting status, the source of diet program, daily frequency of main meals and snacks, BMI groups, and the reason for meal skipping among students according to dietary supplement use $(\mathrm{p}=0.180, \mathrm{p}=0.205, \mathrm{p}=$ $0.686, \mathrm{p}=0.226, \mathrm{p}=0.533, \mathrm{p}=0.449, \mathrm{p}=0.976$, and $\mathrm{p}$ $=0.758$, respectively) (Table 3 ).

There was not any significant difference between physical activity status, the duration of physical activity, dietary supplement use, dieting status, the frequency of main meals and snacks and BMI in terms of total knowledge score of dietary supplements $(\mathrm{p}=0.245, \mathrm{p}=$ $0.713, \mathrm{p}=0.278, \mathrm{p}=0.067, \mathrm{p}=0.466, \mathrm{p}=0.647$, and $\mathrm{p}$ $=0.851$, respectively) (Table 4$)$.
Table 1. Descriptive information about dietary supplement use of participants

\begin{tabular}{|c|c|c|}
\hline & $\mathrm{n}$ & $\%$ \\
\hline \multicolumn{3}{|l|}{ Dietary supplement use } \\
\hline Yes & 95 & 28.5 \\
\hline No & 238 & 71.5 \\
\hline \multicolumn{3}{|l|}{ Supplement type } \\
\hline Multi-vitamin & 24 & 25.3 \\
\hline Omega-3 & 23 & 24.2 \\
\hline Vitamin C & 15 & 15.7 \\
\hline Vitamin D & 14 & 14.7 \\
\hline Probiotic & 8 & 8.4 \\
\hline Vitamin B & 5 & 5.3 \\
\hline Protein powder & 3 & 3.2 \\
\hline Zinc & 2 & 2.1 \\
\hline Other & 1 & 1.1 \\
\hline \multicolumn{3}{|l|}{ Place of purchase } \\
\hline Store & 4 & 4.2 \\
\hline Pharmacy & 91 & 95.8 \\
\hline \multicolumn{3}{|l|}{ Duration of use } \\
\hline Less than 1 month & 13 & 13.7 \\
\hline 1 month & 47 & 49.5 \\
\hline 2 months & 24 & 25.2 \\
\hline 3 months and above & 11 & 11.6 \\
\hline \multicolumn{3}{|l|}{ Purpose of usage } \\
\hline Improve health & 42 & 44.2 \\
\hline Boost immunity & 21 & 22.1 \\
\hline Vitality & 14 & 14.7 \\
\hline Adequate nutrition & 11 & 11.6 \\
\hline Improve performance & 4 & 4.2 \\
\hline Increase muscle mass & 3 & 3.2 \\
\hline
\end{tabular}

\section{Discussion}

The status of nutritional supplement use varies according to the characteristics of the population, countries, and selected samples (Teng et al., 2008; Yahia et al., 2016; Barnes et al., 2016; Gajda et al., 2016; Axon et al., 2017; Kobayashi et al., 2017; Kara, 2019; Naqvi et al., 2019; Radwan et al., 2019; Serdarevic et al., 2019). The frequency of nutritional supplement use in this study population was $28.5 \%$ and it was higher than a study conducted with university students in Turkey (10.7\%) (Kara, 2019). Dietary supplement use is very common among health sciences students and could be higher than the general population (Teng et al., 2008).

While the mainly used dietary supplements were multivitamins (25.3\%) and omega-3 (24.2\%) in our research, in another study $32.5 \%$ of university students used nutritional supplements and vitamins/minerals and $44.2 \%$ used other supplements (Kara, 2019). Similarly, most of the students used vitamin/mineral supplements in Japan and multivitamins in Pakistan and the United Arab Emirates (Naqvi et al., 2019; Radwan et al., 2019). 
Table 2. Comparison of sociodemographic characteristics according to dietary supplement use

\begin{tabular}{|c|c|c|c|c|c|c|}
\hline & Diet & ry sup & lemer & tuse & & \\
\hline & & & & & & \\
\hline & $\mathrm{n}$ & $\%$ & $\mathrm{n}$ & $\%$ & Chi-square & $\mathrm{p}$ \\
\hline Age (year) & & & & & 1.819 & 0.611 \\
\hline 18 and below & 17 & 33.3 & 34 & 66.7 & & \\
\hline 19 & 31 & 25.6 & 90 & 74.4 & & \\
\hline 20 & 23 & 26.4 & 64 & 73.6 & & \\
\hline 21 and above & 24 & 32.4 & 50 & 67.6 & & \\
\hline Gender & & & & & 0.269 & 0.720 \\
\hline Male & 14 & 31.8 & 30 & 68.2 & & \\
\hline Female & 81 & 28.0 & 208 & 72.0 & & \\
\hline Department & & & & & 2.319 & 0.682 \\
\hline Nutrition and Dietetics & 24 & 25.3 & 71 & 74.7 & & \\
\hline Nursing & 17 & 25.8 & 49 & 74.2 & & \\
\hline Child Development & 12 & 27.9 & 31 & 72.1 & & \\
\hline Audiology & 37 & 31.6 & 80 & 68.4 & & \\
\hline Sports Sciences & 5 & 41.7 & 7 & 58.3 & & \\
\hline Coexistent disease & & & & & 3.797 & 0.062 \\
\hline Yes & 20 & 40.0 & 30 & 60.0 & & \\
\hline No & 75 & 26.5 & 208 & 73.5 & & \\
\hline Tobacco smoking & & & & & 1.528 & 0.491 \\
\hline Current smoker & 27 & 32.9 & 55 & 67.1 & & \\
\hline Non-smoker & 62 & 27.8 & 161 & 72.2 & & \\
\hline Former smoker & 6 & 21.4 & 22 & 78.6 & & \\
\hline Alcohol consumption & & & & & 0.842 & 0.658 \\
\hline Drinker & 25 & 31.2 & 55 & 68.8 & & \\
\hline Non-drinker & 67 & 28.2 & 171 & 71.8 & & \\
\hline Former drinker & 3 & 20.0 & 12 & 80.0 & & \\
\hline
\end{tabular}

Students generally purchased supplements from We found no relationships between dietary pharmacies similar to the other studies (Kobayashi et al., supplement use and lifestyle habits. In contrast to our 2017).

In this study, $49.5 \%$ of the students stated supplement use over a one-month period. In another study, the duration of dietary supplement use was found to be $1-3$ months among $34.9 \%$ of Turkish university students (Kara, 2019). When the duration of dietary supplement use of students is taken into consideration, it was found that there were mostly short-term uses in our research. The main reasons for consuming dietary supplements were to improve health $(44.2 \%)$ and boost immunity for our participants. In Turkey, the first two reasons to use nutritional support products for the general population were robustness and immunity in another study (Ünsal et al., 2010).

According to our data, there was no difference between age, gender, department, coexistent disease, tobacco smoking, and alcohol consumption in terms of dietary supplement use. Alfawaz et al. (2017) did not find any significant relationship between age, coexistent disease, and the use of dietary supplements, either. Fattahzadeh-Ardalani et al. (2016) found a significant relationship between age and gender and no significant relationship between educational level and supplement use. These differences in the literature may be due to the sample diversity and sample size. results, in other studies, there were significant associations between supplement use and exercise (Sharma and Adiga, 2014; Lieberman et al., 2015; AlJohani et al., 2018; Radwan et al., 2019). In the literature, supplement users consumed more meals per day as compared to non-users (Radwan et al., 2019). In our participants, those who did not use supplements consumed more meals, but this relationship was not statistically significant.

We also did not find any significant relationship between supplement use and BMI. Similarly, Radwan et al. recorded no significant association of BMI with supplement use (Radwan et al., 2019). In contrast, dietary supplement use had a significant relationship with BMI in Iran (Fattahzadeh-Ardalani et al., 2016).

When the participants' total knowledge score of dietary supplements was examined, their knowledge about supplements was not determinative in our data. No significant correlation was found between the knowledge score and the use of supplements in private sports centers (Helvac1, 2017). On the contrary, the knowledge of dietary supplements was found to be significantly different between supplement users and non-users ( $p$ value $=0.000)$ in college students (Radwan et al., 2019). There might not be sufficient information in the literature about the level of knowledge regarding supplement use 
Table 3. Association between lifestyle habits and dietary supplements use

\begin{tabular}{|c|c|c|c|c|c|c|}
\hline & $\mathrm{Dic}$ & ary sup & lemer & use & & \\
\hline & & es & & & & \\
\hline & $\mathrm{n}$ & $\%$ & $\mathrm{n}$ & $\%$ & Chi-square & $\mathrm{p}$ \\
\hline Physical activity & & & & & 1.991 & 0.180 \\
\hline Yes & 48 & 32.4 & 100 & 67.6 & & \\
\hline No & 47 & 25.4 & 138 & 74.6 & & \\
\hline Duration of physical activi & n./W & & & & 3.031 & 0.205 \\
\hline 90 and below & 22 & 40.7 & 32 & 59.3 & & \\
\hline $90-180$ & 16 & 26.7 & 44 & 73.3 & & \\
\hline 180 and above & 10 & 29.4 & 24 & 70.6 & & \\
\hline Dieting & & & & & 0.330 & 0.686 \\
\hline Yes & 8 & 24.2 & 25 & 75.8 & & \\
\hline No & 87 & 29.0 & 213 & 71.0 & & \\
\hline Source of diet program & & & & & 5.632 & 0.226 \\
\hline Doctor & 1 & 50.0 & 1 & 50.0 & & \\
\hline Dietitian & 3 & 33.3 & 6 & 66.7 & & \\
\hline Physical trainer & 1 & 100.0 & - & - & & \\
\hline Social media & 3 & 15.8 & 16 & 84.2 & & \\
\hline Friend & - & - & 2 & 100.0 & & \\
\hline Main meal (time/d) & & & & & 0.479 & 0.533 \\
\hline 2 & 39 & 30.7 & 88 & 69.3 & & \\
\hline 3 & 56 & 27.2 & 150 & 72.8 & & \\
\hline Snacking (time/d) & & & & & 2.838 & 0.449 \\
\hline 1 & 29 & 27.1 & 78 & 72.9 & & \\
\hline 2 & 58 & 28.7 & 144 & 71.3 & & \\
\hline 3 & 7 & 30.4 & 16 & 69.6 & & \\
\hline 4 & 1 & 100.0 & - & - & & \\
\hline Body Mass Index $\left(\mathrm{kg} / \mathrm{m}^{2}\right)$ & & & & & 0.156 & 0.976 \\
\hline Underweight & 30 & 29.4 & 72 & 70.6 & & \\
\hline Normal & 49 & 27.8 & 127 & 72.2 & & \\
\hline Overweight & 14 & 29.2 & 34 & 70.8 & & \\
\hline Obese & 2 & 28.6 & 5 & 71.4 & & \\
\hline Reason of meal skipping & & & & & 2.750 & 0.758 \\
\hline Lack of habit & 13 & 30.2 & 30 & 69.8 & & \\
\hline Financial difficulties & 1 & 50.0 & 1 & 50.0 & & \\
\hline Waking up late & 2 & 50.0 & 2 & 50.0 & & \\
\hline Inappetence & 7 & 21.9 & 25 & 78.1 & & \\
\hline Lack of time & 12 & 33.3 & 24 & 66.7 & & \\
\hline Desire to lose weight & 4 & 40.0 & 6 & 60.0 & & \\
\hline
\end{tabular}


Table 4. Relationship between lifestyle habits, nutritional status, and total knowledge score of dietary supplements

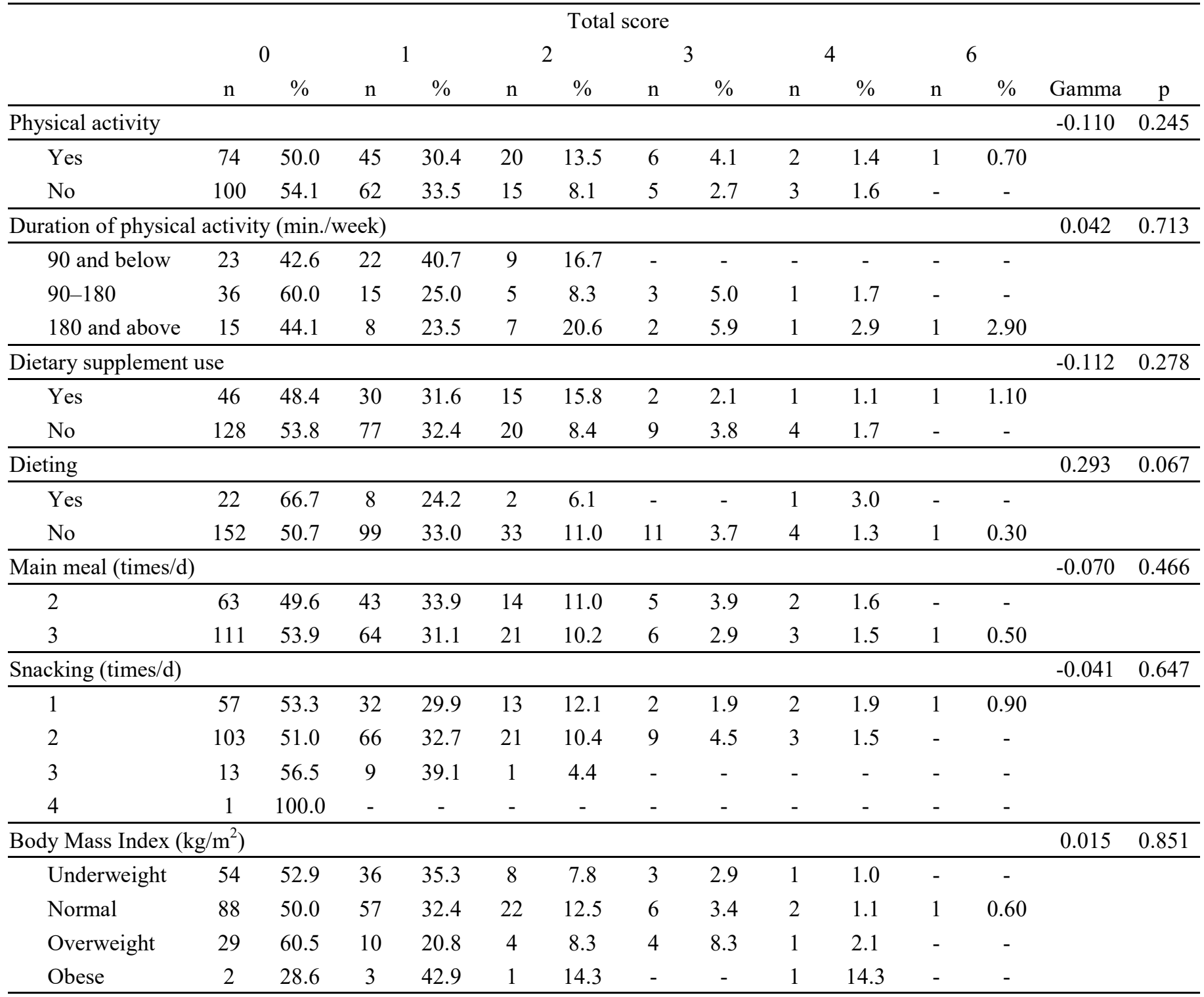

and the related factors.

Conducting the study on a faculty of health sciences had both strengths and limitations. Its strength is that there is an inadequate number of studies that have investigated dietary supplements designed with participants from the field of health sciences in our country. Its weakness is that the students of health sciences do not represent the general university population. On the other hand, studying the effective factors of dietary supplements extensively increases the value of our study.

\section{Conclusion}

Scientific attention should be paid to the use of dietary supplements. Arbitrary approaches can lead to unwanted interactions. Therefore, in order for health and government policies to be established related to dietary supplements, it is essential to determine the factors related to their use. By emphasizing the adequacy of a balanced diet, increasing nutrition education at university programs can positively affect public health by regulating the use of supplements.

\section{Conflict of interest}

The authors declare no conflict of interest.

\section{Acknowledgments}

The authors thank all participants.

\section{References}

Akdevelioğlu, Y. and Yörüsün, T.Ö. (2019). Üniversite öğrencilerinin yeme tutum ve davranişlarina ilişkin bazi faktörlerin incelenmesi. Gazi Sağllk Bilimleri Dergisi, 4(1), 19-28.

Al-Johani, W.M., Al-Dawood, K.M., Wahab, M.M.A. and Yousef, H.A. (2018). Consumption of vitamin and mineral supplements and its correlates among medical students in Eastern Province, Saudi Arabia. Journal of Family and Community Medicine, 25(3), 169-174. 
Alfawaz, H., Khan, N., Alfaifi, A., Shahrani, F.M., Al Tameem, H.M., Al Otaibi, S.F., Abudigin, W.I., AlShayaa, M.S., Al-Ghanim, S.A. and Al-Daghri, N.M. (2017). Prevalence of dietary supplement use and associated factors among female college students in Saudi Arabia. BMC Women's Health, 17(1), 116. https://doi.org/10.1186/s12905-017-0475-y

Arslan, S.A., Daşkapan, A. and Çakır, B. (2016). Üniversite öğrencilerinin beslenme ve fiziksel aktivite alışkanlıklarının belirlenmesi. TAF Preventive Medicine Bulletin, 15(3), 171-180. https://doi.org/10.5455/pmb.1-1436432564

Axon, D.R., Vanova, J., Edel, C. and Slack, M. (2017). Dietary supplement use, knowledge, and perceptions among student pharmacists. American Journal of Pharmaceutical Education, 81(5), 92. https:// doi.org/10.5688/ajpe81592

Babal, A.F. (2015). Research of Supplement Using and Nutritional Habits Who Makes Exercise. Istanbul: Haliç University, MSc. Thesis.

Barnes, K., Ball, L., Desbrow, B., Alsharairi, N. and Ahmed, F. (2016). Consumption and reasons for use of dietary supplements in an Australian university population. Nutrition, 32(5), 524-530. https:// doi.org/10.1016/j.nut.2015.10.022

Bozkurt Bekoğlu, F. and Ergen, A. (2016). Views Regarding Dietary Supplements in Turkey and a Research to Profile the Consumers. Journal of Business Research-Türk, 8(1), 323-341. https:// doi.org/10.20491/isader.2016.147

Erden, B.F. and Tanyeri, P. (2004). Ülkemizde vitamin ve mineral eklentilerin akılcı kullanımı. Sürekli tıp eğitimi dergisi, 13, 411-414. [In Turkish].

EC (European Commission). (2020). Food supplements. Retrieved on July 20, 2020 from EC Website: https:// ec.europa.eu/food/safety/labelling_nutrition/ supplements.

EFSA (European Food Safety Authority). (2020). Food supplements. Retrieved on July 20, 2020 from EFSA Website: http://www.efsa.europa.eu/en/topics/topic/ food-supplements

Fattahzadeh-Ardalani, G., Farzaneh, E., Fathi, A., Molaei, B. and Valizadeh, M. (2016). Determining the prevalence of dietary supplement consumption among Ardabil University students and related factors, 2014. International Journal of Community Medicine and Public Health, 3(1), 224-229. https:// doi.org/10.18203/2394-6040.ijcmph20151567

Gajda, K., Zielinska, M., Ciecierska, A. and Hamulka, J. (2016). Determinants of the use of dietary supplements among secondary and high school students. Roczniki Państwowego Zaktadu Higieny, 67(4), 383-390.

Helvac1, G. (2017). The tendency of individuals actively involving in exercise in private sports centers to use nutritional supplements and their awareness of the products. Istanbul, Turkey: Haliç University, MSc. Thesis.

Kara, B. (2019). Determining the use of dietary supplements among university students. Gaziantep: Hasan Kalyoncu University, MSc. Thesis.

Karaarslan, T., Özdemir, E. and Sungur, S. (2008). Besin Destek Ürünleri ve İlaçlarla Etkileşimleri: Vitamin ve Mineraller. Ankara, Turkey: Ministry of Health.

Kartal, M., Bucak, F.K. and Balcı, E. (2017). Nutrition culture of university students. Sağllk Akademisyenleri Dergisi, 4(4), 332-338. https:// doi.org/10.5455/sad.13-1511164129

Kobayashi, E., Sato, Y., Umegaki, K. and Chiba, T. (2017). The prevalence of dietary supplement use among college students: a nationwide survey in Japan. Nutrients, 9(11), $1250 . \quad$ https:// doi.org/10.3390/nu9111250

Kosic, A., Lindholm, P., Järvholm, K., HedmanLagerlöf, E. and Axelsson, E. (2020). Three decades of increase in health anxiety: Systematic review and meta-analysis of birth cohort changes in university student samples from 1985 to 2017. Journal of Anxiety Disorders, 71, 102208. https:// doi.org/10.1016/j.janxdis.2020.102208

Lieberman, H.R., Marriott, B.P., Williams, C., Judelson, D.A., Glickman, E.L., Geiselman, P.J., Dotson, L., and Mahoney, C.R. (2015). Patterns of dietary supplement use among college students. Clinical Nutrition, 34(5), 976-985. https://doi.org/10.1016/ j.clnu.2014.10.010

Naqvi, A.A., Ahmad, R., Zehra, F., Yousuf, R., Kachela, B. and Nehal Nadir, M. (2019). Dietary supplement use among students of pharmacy colleges in the City of Karachi, Pakistan: prevalence, opinions, and attitudes. Journal of Dietary Supplements, 16(2), 166 -178 .

https:// doi.org/10.1080/19390211.2018.1443191

Radwan, H., Hasan, H. A., Ghanem, L., Alnajjar, G., Shabir, A., Alshamsi, A. and Alketbi, F. (2019). Prevalence of dietary supplement use and associated factors among college students in the United Arab Emirates. Journal of Community Health, 44(6), 1135 -1140. https://doi.org/10.1007/s10900-019-00700-2

Serdarevic, N., Katana, B., Jaganjac, A., Bojicic, S., Brankovic, S. and Mahmutovic, J. (2019). The Cigarette Smoking, Coffee and Supplements Intake at Students of Sarajevo University. Medical 
Archives, 73(2), 104-108. https://doi.org/10.5455/ medarh.2019.73.104-108

Sharma, A. and Adiga, S. (2014). Knowledge, attitude and practices related to dietary supplements and micronutrients in health sciences students. Journal of Clinical and Diagnostic Research, 8(8), HC01-HC04 https://doi.org/10.7860/JCDR/2014/9329.4683

Tek, A. and Pekcan, G. Besin Destekleri Kullanilmalı mı? (2008). Ankara, Turkey: Ministry of Health. [In Turkish].

Teng, C.L., Tey, K.K., Lim, P.H., Cheng, S.F., Nordin, M.S., Ng, C.M., Zakaria, W.N.W. and Wong, K.Y. (2008). Dietary supplements: usage and opinions among health sciences students. International $e$ Journal of Science, Medicine and Education, 2(2), 30-32.

Ünsal, G.N., Özdemir, G. and Ersoy, G. (2010). The assessment of the consumer awareness in nutritional support products usage. Sağglı Bilimleri Tip Dergisi, Firat Üniversitesi, 24(2), 81-88.

WHO (World Health Organisation) (2020). Body Mass Index. Retrieved on July 20, 2020 from WHO Website: https://www.euro.who.int/en/health-topics/ disease-prevention/nutrition/a-healthy-lifestyle/body -mass-index-bmi

Yahia, N., Wang, D., Rapley, M. and Dey, R. (2016). Assessment of weight status, dietary habits and beliefs, physical activity, and nutritional knowledge among university students. Perspectives in Public Health, 136(4), 231-244. https:// doi.org/10.1177/1757913915609945

Zemzemoğlu, T.E.A., Erem, S., Uludağ, E. and Uzun, S. (2019). Sağlik bilimleri fakültesi öğrencilerinin beslenme alişkanliklarinin belirlenmesi. Food and Health, 5(3), 185-196. https://doi.org/10.3153/ FH19020 